Ольга БІЛОБРОВЕЦЬ, orcid.org/0000-0001-6638-3815 кандидат історичних наук, дочент кафедри історії України Житомирського державного університету імені Івана Франка (Україна, Житомир) bilobrovets@gmail.com

\title{
ПОЛЬСЬКА СУСПІЛЬНО-ПОЛІТИЧНА ДУМКА В УКРАЇНІ ЩОДО ПОЛІТИКИ ГАЛИЦЬКИХ ПАРТІЙ У ВИРІШЕННІ ПОЛЬСЬКОГО ПИТАННЯ (1914 - 1916 рр.)
}

У статті показано обставини формування польської суспільної думки в Україні щодо позицій польських партій на Галичині у розв'язанні польського питання. Переважання русофільської орієнтачії і боротьби за автономію, несприйняття галищького «активізму» більшістю поляків в Украӥні в перші роки війни змінилося з ходом війни на необхідність відродження незалежної польської держави. 3 категоричних і протилежних позицій з головних питань державного життя польські політичні сили у різних частинах розділеної Польщі перейшли до діалогу і пошуку компромісів.

Ключові слова: польське питання, суспільно-політична думка, «активізм», «пасивізм», «нейтралізм».

Jim. 25.

Ol'ha BILOBROVETS,

Ph D (History), Associate Professor of Department of Ukraine's History, Zhytomyr Ivan Franko State University (Ukraine,Zhytomyr)bilobrovets@gmail.com

\section{POLISH SOCIAL-POLITICAL OPINION IN UKRAINE ON THE POLICY OF THE GALICIAN PARTIES IN SOLVING THE POLISH QUESTION IN 1914 - 1916}

The article shows the circumstances of the formation of Polish public opinion in Ukraine about the positions of the Polish parties in Galicia in solving the Polish question. The predominance of the Russophile orientation and the struggle for autonomy, the rejection of Galician «activism» by the majority of Poles in Ukraine in the first years of the war changed with the course of the war into a necessity of the revival of an independent Polish state. Polish political circles in different parts of the divided Poland turned from categorical and diametrically opposed positions in the main issues of state life to dialogue and search for compromises.

On the eve of the First World War Polish political circles set the restoration of statehood as their main task of solving the Polish question. At the beginning of the war, the political milieu, extended in the territories divided between Austria, Russia and Prussia, supported the governments of their corresponding countries.

In Russia supporters of the Russophile direction, or "passivists», prevailed and the party of National's Democrats represented their interests. In Galicia was the camp of the "activists», that included the majority of the Polish parties, which focused on Austria-Hungary and Germany. Part of the Polish parties in Galicia and the Kingdom relied on the support of the European coalition countries. It was a group of «neutralists». An attempt to unite the two positions and develop a common Polish policy existed yet before the war, but during the war, despite the creation of various central institutions, there was no single policy regarding the ways of the revival of the future Polish state, its structure and the necessity to organize the Polish army.

These approaches were presented in the programs of Polish political parties, voiced by their leaders, political and public figures, and became the subject of discussion on the pages of the press, especially Polish. Since the beginning of the war in the Kievan Polish press the policy of Galician activists was condemned, and that was reflected in the recalls of Polish parties and newspaper articles. Polish society in Russia hoped to fulfill the promises of the power to give the Poles an autonomy on the basis of uniting all of Poland. With the war, the number of human victims, destruction and refugees increased so, that the Polish society reappraised Galician policy and the transition to a position of struggle for the independence of the Polish state. All the Polish society, finally, confirmed the need for the struggle for Poland's independence after the proclamation by the central states of the independence of the Kingdom of Poland.

Key words: social-political opinion, Polish question, «activism», «passivism», «neutralism».

Ref. 25. 
Ольга БЕЛОБРОВЕЦ,

кандидат исторических наук, доиент кафедры истории Украинь

Житомирского государственного университета имени Ивана Франко

(Украина, Житомир) bilobrovets@gmail.com

\section{ПОЛЬСКАЯ ОБЩЕСТВЕННО-ПОЛИТИЧЕСКАЯ МЫСЛЬ В УКРАИНЕ О ПОЛИ- ТИКЕ ГАЛИЧСКИХ ПАРТИЙ В РЕШЕНИИ ПОЛЬСКОГО ВОПРОСА (1914 - 1916 ГГ.)}

В статье показаны обстоятельства формирования польской общественной мысли в Украине относительно позиции польских партий в Галиции в ретении польского вопроса. Преобладание руссофильской ориентаичи и борьбы за автономию, не восприятие галичского «активизма» больиинством поляков в Украине в первые годы войны изменилось с ходом войны на необходимость возрождения независимого польского государства. От категорических и противостоящих позищий в главных вопросах государственности польские политические силь в разных частях разделенной Польши перешли к диалогу и поиску компромиссов.

Ключевые слова: польский вопрос, общественно-политическая мысль, «активизм», «пассивизм», «нейтрализм».

Лum. 25.

Постановка проблеми. Польська справа як вирішення питання відновлення польської державності одержала новий імпульс для свого розв'язання в роки Першої світової війни. Польські політичні партії в Росії і Галичині бачили різні шляхи для ії вирішення і спиралися на різні військово-політичні союзи. Реалізація незалежницьких прагнень народів через використання кризових історичних моментів, сприятливої зовнішньої кон'юнктури і подолання внутрішніх партійних суперечностей $є$ актуальною проблемою сьогодення. Показовим у цьому сенсі $\epsilon$ пошук кращих варіантів розв'язання національних завдань, вплив на це суспільно-політичної думки і конкретних обставин діяльності польських політичних сил в Галичині в перші роки Першої світової війни.

Аналіз досліджень. Питання ставлення європейських держав до розв'язання польського питання у ході Першої світової війни, шляхи відновлення державності польськими політичними силами і громадськістю, перші кроки відбудови незалежної держави досліджувались радянськими, польськими й українськими істориками. Зокрема, це праці близького за часом до відображуваних подій С. Кутшеби [16]. Аналізу суспільно-політичного життя поляків у всіх розділених частинах Польщі під час війни присвятив свої роботи Я. Лєвандовський [17]. Розв'язання польського питання у контексті загальноєвропейської політики розглядали Я. Паєвський [20], С. Сєрповський [22]. Становлення державності II Речі Посполитої у 1914 - 1921 рр. досліджував В. Боєчко [1] та ін. Однак період Першої світової війни і розглянута загалом проблема відновлення польської держави виявила достатньо конкретних питань і тем для сучасних досліджень.

Мета дослідження. Пропонована стаття ставить своїм завданням з'ясувати обставини формування та вплив польської суспільної думки в Україні на шляхи розв'язання польського питання через призму галицької політики, представленої польськими партіями та інституціями.

Виклад основного матеріалу. Відновлення польської державності було головним питанням у діяльності практично всіх польських політичних партій наприкінці XIX ст. 3 початком Першої світової війни польське суспільство, розділене між трьома державами, бачило свої шляхи його розв'язання. Польське населення в Росії з великим ентузіазмом підтримало російський царизм у війні, сподіваючись на швидку його перемогу і одержання національної самостійності. Впевненості у цьому надало звернення Верховного головнокомандуючого, Великого князя Миколи Миколайовича до поляків з обіцянкою «відродження Польщі, вільної у своїй вірі, мові і самоуправлінні» $[2,3]$.

Характеризуючи політичні настрої польського населення, начальник Київського губернського жандармського управління у серпні 1914 р. виділив серед нього чотири групи. Найбільш багаточисельну групу складали поляки, які вважали себе задоволеними, тому завдяки їх лояльності до російського уряду, а не через польську кров, пролиту в повстаннях, можна буде відновити державність. Досить значна група осіб, так званої «русофільської орієнтації» вважала, що добитися самостійності можливо тільки опираючись на якусь сильну країну. До початку війни такою вва- 
жалася Австрія, а після відозви Верховного головнокомандуючого, їх сподівання були звернуті до Росії. Незначна група осіб вважали, що російський уряд у тяжку хвилину змушений використовувати всі засоби і тому пообіцяв полякам бажану автономію у відповідь на їх підтримку у війні. Ще одна група поляків вважали перехід на позиції підтримки Росії зрадою національних інтересів, що призведе до братовбивчої війни. Це, так звана, група «австрофільської орієнтації» [11, 301].

Виразниками польської суспільної думки були керівники польських партій, політичні, державні, громадські діячі, які представляли свої погляди, передусім на сторінках друкованих видань. У роки світової війни в Україні найбільш популярними польськими виданнями були щоденна газета «Дзєннік Кійовськи» (Dziennik Kijowski), тижневики «Клоси Українське» (Kłosy Ukraińskie) у Києві і «Тигоднік Одеськи» (Tygodnik Odeski) в Одесі. Редакція «Дзєнніка Кійовского» перебувала під впливом народової демократії. На сторінках газет відбувалися дискусії з важливих питань національного і суспільно-політичного життя, шляхів їх розв'язання.

Представником польської думки в Росії була найбільш поширена серед польського населення партія Народових демократів (народовців або ендеків) на чолі з Р. Дмовським. Її члени проводили активну політичну і державну діяльність, будучи депутатами Державної думи і Державної ради. Народовці займали русофільську позицію і боролися за створення автономії у межах Росії законодавчим шляхом. Як зазначав Р. Дмовський, головним у передвоєнний час і в перші роки війни було забезпечення самостійності польської політики і визнання польського питання $[13,175]$.

У серпні 1914 р. у Галичині був створений Головний національний комітет (ГНК) (Naczelny Komitet Narodowy). За донесенням начальника штабу військового генерал-губернатора Галичини тут поширились прокламації «До поляків», які закликали польське населення до об'єднання 3 «Головною командою Австро-угорської армії» і до боротьби з російським урядом. До складу президії ГНК, який підписав звернення, входили: голова - Юлій Лео, голова Польського Кола у Відні, його заступники - К. Абрагамович, Л. Герман, А. Скарбек. Членами Комітету були представники всіх політичних груп. Зокрема, Т. Цінський, кн. В. Чарторийський, І. Дашинський В. Яворський, гр. 3. Тарновський, загалом близько 40 осіб [10, 78].

Характеристику діяльності ГНК було дано в аналітичній записці з польського питання департаментом поліції Київського ГЖУ. Головний національний комітет було створено із об'єднання двох великих політичних організацій «Тимчасової комісії» $\mathrm{i}$ «Ради народової», які існували напередодні війни. Перша з них об’єднувала всі крайні ліві польські групи до соціалістів включно і наполягала на необхідності австрофільської орієнтації і нещадній боротьбі з Росією. Друга організація, до складу якої увійшли помірковані групи (автономісти, клерикали, народова демократія та ін.), навпаки, дотримувалась у своїй діяльності русофільських настроїв. Обидві групи бачили різні шляхи досягнення самостійності Польщі. «Тимчасова комісія» вважала єдиним шляхом позбавлення російського панування збройний виступ і союз з центральними країнами. «Рада народова» відстоювала політичну платформу об'єднання з Росією.

Війна, яка розпочалася раптово, захопила два угруповання несподівано і неготовими до такого ходу подій. Після оголошення Австро-Угорщиною мобілізації члени стрілецьких організації почали записуватися до її армії. Голова польських стрільців Ю. Пілсудський, побоюючись розчинитися в австрійській армії, самостійно вдерся на територію Росії із загоном у 400 осіб. Цей вчинок Ю. Пілсудського викликав серед поміркованих польських патріотів вибух, у тому числі і незадоволення. У цей час, в серпні 1915 р. у Відні відбулась конференція польських політичних груп, згідно з рішеннями якої у Кракові як центральний орган тимчасового польського уряду було утворено Головний національний комітет. Головою його було вибрано голову м. Краків доктора Лео, поміркованого прогресиста. До Комітету увійшли як ліві угруповання з «Тимчасової комісії», так і представники поміркованих груп, в тому числі і деякі члени «Ради народової». Однак внаслідок неможливості впливу на діяльність Комітету, вони вийшли з нього [8, 15].

Відозва Головного національного комітету у Кракові до всіх поляків із закликом підтримати Австро-Угорщину у боротьбі з Росією викликала негативну реакцію польських політичних сил в Росії. На сторінках тижневика «Клоси Українське» було надруковано відозви польських політичних партій з позицією у цьому питанні. Партія реальної політики і Народово-демократична партія надіслали 28 серпня з Варшави до Кракова резолюцію, в якій обстоювали необхід- 
ність підтримки російсько-французько-англійської коаліції, що дає польському народові перспективи об'єднання всіх польських земель з доступом до Балтійського моря, тоді, коли перемога німецько-австрійського союзу повинна привести до нового поділу Польщі, продиктованого передусім Пруссією. Зазначалося, що «Росія виступила з програмою у вирішенні польського питання у відозві Великого князя, з ентузіазмом сприйнятою англійською і французькою думкою, в той час, коли Австрія у цілому польське питання не поставила до вирішення, що зрештою очевидно 3 відозви галицького Кола Польського» $[18,25]$.

Своє ставлення до відозви НКН у Галичині надала і Польська Прогресивна партія (Polska Partia Postupowa). У iï відозві увага акцентувалась на необхідності об'єднання усіх частин Польщі, які може забезпечити лише коаліція європейських держав. Передусім Росія першою урочисто оголосила своїм союзникам і всьому світові у відозві Верховного головнокомандуючого до поляків, що вважає обов'язком усіма силами подолати ворога і знову відродити з трьох розділених частин єдину Польщу, яка охоплює і ті території, які загарбала Пруссія. Наголошувалось, що «Австрія відіграє допоміжну роль, роль держави, яка виконує і буде виконувати накази Німеччини, і власне Пруссії» $[18,26]$.

Польське прогресивне об'єднання (Polskie Zjednoczenie Postupowe) також окреслило своє ставлення до відозви галицького НКН. Позиція партії полягала у тому, що перемога Німеччини над європейською коаліцією не тільки віддалить гаряче очікуване об'єднання вітчизни, але і подальшу германізацію ще більшої частини Королівства. До цих партій долучилися і представники політичного руху, названого в Галичині «вшехпольським», які ще перед здобуттям Львова звинуватили членів Кола Польського у Відні, які «у тяжкий час не зрозуміли свою відповідальність і свій обов'язок, закликаючи поляків до війни з Росією і забули про одвічних ворогів - прусаків» $[18,26]$.

Прихильниками Росії, в основному народовцями, у листопаді 1914 р. у Варшаві був утворений Польський національний комітет (Polski Komitet Narodowy), який поставив завдання шляхом об'єднання всіх поляків, незалежно від їх поглядів і переконань, сприяти реалізації вказівок, окреслених у відозві Верховного головнокомандуючого. До складу Комітету увійшли члени Державної думи і Державної ради і громадські діячі Королівства Польського $[3,3]$. Комітет звернувся з відозвою до всіх поляків, у якій висловив сподівання, що перемога поляків буде поразкою Німеччини. У ній зазначалось, що для прискорення перемоги, польська молодь почала записуватися до російської армії, яка «вже ступила на рідну польську землю, що належала Австрії і треба очікувати їі вступу до одвічних наших садиб, які залишаються під пануванням Прусії» $[18,26]$.

Із наближенням російських військ до Кракова, голова Головного національного комітету в Кракові доктор Лео залишив місто і головою Комітету було обрано проф. В. Яворського. Період пожвавлення діяльності прихильників проросійської орієнтації тривав до травня 1915 р. [5, 15зв.]. У цей час до Галицько-Буковинського генерал-губернатора гр. Г. Бобринського звертався голова Польської народово-демократичної партії у Галичині проф. Львівського університету В. Грабський з проханням дозволити йому у січні 1915 р. провести у Львові зібрання відомих поляків для обговорення питань, пов'язаних з війною і долею польських провінцій Росії, Австрії і Пруссії. Він сподівався, що йому вдасться зібрати у Львові близько 100 найвідоміших людей краю усіх партій як із губерній Королівства Польського, так із інших територій. Мета зібрання полягала у необхідності переконання усіх поляків приєднатися до загальнопольського руху на користь Росії. При цьому В. Грабський додавав записку, в якій коротко виклав права, якими польське населення Галичини користувалося за часів австрійського володіння і ескіз відозви до поляків при введенні військово-громадянського управління у Західній Галичині, яке, на думку Грабського, необхідно оприлюднити, щоб остаточно переконати тих поляків, які мають сумнів у щирості намірів російського уряду. Основою майбутнього самоуправління Польщі мало бути вільне користування польською мовою, свобода віросповідання, законодавча і адміністративна автономія у всіх справах, що стосуються майбутнього устрою Польщі $[9,39]$.

Відповідь на цю пропозицію надійшла від російського імператора Миколи II, який вважав це зібрання недоцільним, оскільки на посаду Варшавського генерал-губернатора вже призначений князь П. Снгаличов, який виголосить промову, в якій буде окреслено шляхи розв'язання поль- 
ського питання на основі принципів, закладених у відозві Верховного головнокомандуючого. Однак зібрання представників із Королівства Польського, Галичини і Познані можливе після взяття Перемишля і промови губернатора $[9,51]$.

3 відходом російської армії з Галичини, австрійська влада спочатку провела певні репресивні заходи щодо польського населення, підозрюючи його в лояльності до росіян, а восени того ж року змінила своє ставлення до поляків з метою залучення його на свій бік. При цьому колишньому польському міністру фінансів у Галичині Л. Білінському було доручено схилити керівні польські кола до об'єднання на основі австрофільської орієнтації. Однак всупереч проханням польських соціалістів, ніяких конкретних рішень щодо майбутнього устрою Польщі австрійський уряд не запропонував, тому місія Білінського зазнала невдачі і не завершилась об'єднанням польського суспільства.

Незважаючи на існування різних польських головних комітетів і рад, спільного органу, який би визначав єдину польську політику і репрезентував польське суспільство, не було. Про це у статті «Клосів Українських» писав Т. Гарчинський, вказуючи, що чинні польські комітети вимагають дотримуватись їх вимог і займати запропоновану ними позицію, вважаючи злочинцями усіх, хто виступає проти. Коли ж їх розпорядження не підтримуються і не знаходять відгуку у пресі, вони називають це зрадою. Він вважав, що Комітети повинні висловлювати суспільну думку народу, щоб бути підтриманими $[14,3]$.

Наприкінці 1915 р. у Варшаві було організовано «Головний комітет об'єднаних незалежних союзів», який вважав центральні країни своїми союзниками і був переконаний, що внутрішня польська робота нічим не перешкоджає життєвим інтересам і завданням цих держав». Більшість союзів, що мали назву «незалежних», групувалися навколо Краківського Головного національного комітету, але до них не належали: «Союз реальної політики», «Союз Народової демократії», «Прогресивний союз» і декілька менших груп [7, 161].

Лише наприкінці 1915 р. завдяки добре організованій широкій агітації прихильників австрійської політики у Варшаві відбулася конференція представників лівих польських політичних груп, які закликали об'єднатися навколо Головного національного комітету і вимагати від австрійської і німецької влади розв'язання польського питання. Одночасно таке ж об'єднання під зверхністю ГНК відбулось і в Галичині [8, 15зв.].

На початку січня 1916 р. у Відні відбулась дискусія і обмін думками польських політиків. У конференції взяли участь голова Польського Кола у Відні доктор Л. Білінський, керівник Головного національного комітету - доктор В. Яворський, депутат парламенту соціаліст І. Дашинський, представник незалежних груп - доктор В. Сікорський. Було визнано, що головним завданням у польському русі є досягнення згоди і вироблення спільної політики. Визнано, що Польське Коло $\epsilon$ політичним союзом, що відповідає парламентським потребам, а ГНК - суспільною організацією і тому їм необхідно поділити сфери впливу при виробленні спільної політики. Одностайно вирішено, що керівництво ГНК буде здійснювати голова Польського Кола, один з найдосвідченіших польських державних діячів - доктор Білінський $[25,9]$.

Діалог народовців, які складали табір «пасивістів» і були прихильниками Росії, з Головним національним комітетом, в якому переважали активісти - політичні групи соціалістичного спрямування австрофілької орієнтації на чолі Ю. Пілсудським, став можливим в умовах затягування війни і невирішеності даних полякам обіцянок російською владою. У січні 1916 р. зі згоди австрійського і німецького урядів у Кракові відбулася загальна конференція представників усіх трьох розділених частин Польщі, в якій взяли участь також члени Державної думи А. Парчевський і М. Лемпіцький та ін. помірковані ліберали. На цій конференції гр. А. Тарнавський від імені австрійського уряду за згодою німецького уряду заявив, що воно йде назустріч побажанням поляків об'єднати Царство Польське з Галичиною під скіпетром Габсбургів. За цим планом тільки Познань буде належати Німеччині з компенсацією приєднання до Польщі деяких російських областей з виходом до моря. Така пропозиція загалом була прийнята учасниками конференції $\mathrm{i}$ було вирішено повідомити російських поляків і обговорити з ними це питання на майбутньому загальнопольському конгресі. 3 цією метою було запропоновано організувати у Стокгольмі, Бухаресті і Лозанні особливі польські інформаційні бюро для ознайомлення закордонних поляків про 
хід польських справ. Після цього почалась робота з переконання польських лідерів у Росії про підтримку такого плану [8, 15зв.].

На початку лютого 1916 р. керівники партії Народових демократів Р. Дмовський, В. Чарторийський, Е. Пільц, Т. Скаржинський були присутніми на польському з’їзді в Лондоні, на якому розглядались питання майбутньої долі Польщі $[5,3]$.

Упродовж 1916 р. продовжувалась політична консолідація Польщі за кордонами Росії, в якій виразно відзначалася політика самостійності. Т. Яворський у газеті «Дзєннік Кійовськи» у статті «Політична консолідація Польщі» пише, що з видимого хаосу виринає щораз яскравіше ідея, найдорожча для серця кожного поляка, як категоричний імператив - самостійність. Він вказує, що «дух Польщі, вирваний з кола терпіння і жертв, став на дорогу, по якій у звичайний час треба йти десятки, а то й сотні років» $[15,1]$.

Відомості, які доходили до польської громадськості у Росії щодо діяльності польських партій у Галичині і Королівстві Польському були уривчастими і важко відтворювали дійсний стан речей, про що писав головний редактор газети «Дзєннік Кійовськи» Е. Пашковський. «Однак, знаємо, що там панує загальна польська орієнтація на незалежність, що усілякі суперечки, тертя і боротьба відбуваються виключно стосовно тактичних питань. Королівство Польське, Галичина і Великопольща в загальній масі визнають необхідність нейтральності, виходячи з того, що сила обставин позбавила Польщу подальшої свободи руху» [21, 1].

Наприкінці 1916 р. з'явилися відомі акти незалежності, видані австрійським і німецьким урядом. 05.11.1916 р. німецький генерал-губернатор у Варшаві Безелер оголосив населенню маніфест такого змісту: «Німецький імператор та австрійський імператор і король Угорщини, спираючись на непохитну впевненість в перемозі своєї зброї і прагнучи прокласти шлях у щасливе майбутнє польським провінціям, які ціною значних жертв були відібрані у Росії, дійшли до порозуміння, щоб у цих провінціях утворити самостійну державу з власним урядом і монархічно-конституційним устроєм. Точніше визначення кордонів Королівства Польського відбудеться у майбутньому». Аналогічна відозва була оголошена австро-угорським генерал-губернатором у Любліні, генерал-зброймістром Куком [24, 25].

Ці документи викликали неоднозначну реакцію у польському суспільстві. Представники Народової демократії виступили з протестом проти проголошення незалежності Польщі на окупованих німцями відібраних у Росії територіях. «Польська нація нероздільна і прагне до створення польської держави з трьох роз'єднаних частин. Австрія і Німеччина перетворюють утворену державу на інструмент своєї політики. Цей акт є тяжким лихом для Польщі і новою акцією її поділу» $[6,2]$. Із запереченням актів центральних держав виступило Міжпартійне Польське Коло (МПК), утворене в листопаді 1915 р. у Галичині, яке стояло на позиціях «нейтралізму», прихильності до коаліційних країн. У зв'язку з оголошенням незалежності дві партії - Національна партія і Прогресивне об'єднання - вийшли з МПК і приєдналися до позиції «активістів», які підтримували акти. Решта партій - Реальної політики, Народової демократії, Польської прогресивної партії, Національного об'єднання - виступили із заявою, в якій оголосили акти такими, що не відповідають прагненням польського народу [12, 21].

Головний редактор газети «Клоси Українське», даючи оцінку цим документам, зазначив, що «акти про незалежність - це є тільки урочиста декларація, що Німеччина і Австро-Угорщина визнають необхідність незалежної польської державності». Однак він уважав, що їхнє значення полягає у тому, що «цими актами польська справа виходить на новий історичний етап, що польське питання стає на переломний шлях. Ідея незалежності забирає можливість ставити польське питання на основу автономності і підкреслює необхідність міжнародного втручання» [24, 25].

3 проголошенням незалежного Королівства Польського було організовано вибори до польської державної ради - сейму під назвою «Тимчасова рада Стану». Вибори проходили на 32 виборчих дільницях, право обирати належало громадянам Королівства Польського. Участь у роботі Ради Стану взяли представники політичних сил Галичини. 325 членів Ради Стану 10 представляли австро-німецьку окуповану територію $[4,2]$.

Головне значення прийнятих актів про проголошення незалежності Королівства Польського для польського суспільного руху полягало у тому, що остаточно відбувся перехід польської сус- 
пільної думки в Росії з позицій боротьби за автономію на позиції утвердження незалежності польської держави. У статті відомого політичного діяча демократичного напряму, публіциста Є. Старчевського підкреслювалось, що акт про незалежність Королівства Польського є продуктом розрахунку центральних держав, але полякам безрозсудно було не використати такий шанс. Він нагадує російським демократам, що «польський народ має право прагнути не автономії, а незалежності». Він вважав, що поляки повинні об'єднатися навколо національних ідеалів, зректися автономістських прагнень і об’єднуватися навколо спільного для всіх ідеалу - незалежної етнографічної Польщі $[23,1]$.

У російській демократичній пресі, у газеті «День», констатуючи польські настрої в Росії, відзначалося, що «Акт 5 листопада усунув з порядку денного «автономне» вирішення польського питання, і в тому полягало його політичне значення» $[19,2]$. Суперечки Народової демократії, яка орієнтувалася на Росію, «нейтралістів», прихильників коаліційних країн і «активістів», що вбачали свою основну опору у центральних країнах і представлених в основному у Галичині у розв'язанні польського питання у післяреволюційний період вийшли на новий рівень, викликавши появу у 1917 - 1918 рр. нових державотворчих документів й існування нових національних, суспільно-політичних інституцій.

Висновки. На початку війни на польських територіях, розділених Австрією, Росією і Пруссією, польські політичні сили підтримали уряди своїх країн. У Росії переважали прихильники русофільського напрямку, або ж «пасивісти», і їх виразниками була партія Народових демократів. У Галичині табір «активістів», до якого входила більшість польських партій, була австрофільської спрямованості і орієнтувалася на центральні країни - Австро-Угорщину і Німеччину. Частина польських партій в Галичині і Королівстві розраховувала на підтримку країн європейської коаліції і складала групу «нейтралістів». Спроба об’єднання різних позицій і вироблення спільної польської політики існувала ще напередодні війни, однак впродовж війни, незважаючи на створення різних центральних інституцій, єдиної політики стосовно шляхів відродження майбутньої польської держави не було.

Означені підходи були представлені в програмах польських політичних партій, озвучені їх лідерами, політичними і громадськими діячами і стали предметом дискусії на сторінках преси, передусім польської. У київських польських виданнях «Дзєннік Кійовськи» і «Клоси Українське» 3 початку війни політика галицьких активістів засуджувалася, що знайшло своє відображення у відозвах польських партій, публіцистиці. 3 ходом війни, зростанням людських жертв і руйнацій, великою кількістю біженців і відсутністю розв'язання польського питання російською владою у польському суспільстві відбувається переоцінка галицької політики і перехід від боротьби за автономію на позиції необхідності самостійності польської держави. Остаточне утвердження незалежницьких настроїв у суспільстві наступило після проголошення центральними державами незалежного Королівства Польського.

\section{СПИСОК ВИКОРИСТАНИХ ДЖЕРЕЛ І ЛІТЕРАТУРИ}

1. Боєчко В. Друга Річпосполита 1914 - 1921 рр.: становлення державності / В. Боєчко. - Черкаси: ЧНУ, 2016. -408 с.

2. Державний архів Львівської області. - Ф. 350 (Дирекція поліції у Львові Галицького намісництва). - Оп. 1. - Спр. 3506 (Відозва російського імператора Миколи I до польського населення). - 4 арк.

3. Польский национальный комитет // Наша Волынь. - Житомир. - 1914. - № 302. - С. 3.

4. Польский сейм // Жизнь Волыни. - Житомир. - 1916. - № 314. - С. 2.

5. Польский съезд // Жизнь Волыни. - Житомир. - 1916. - № 39 - С. 3.

6. Протест поляков // Жизнь Волыни. - Житомир. - 1916. № 301 - С. 2.

7. Центральний державний історичний аріхів України у м. Києві (далі - ЦДІАК України). - Ф. 274 (Киевское ГЖУ) - О. 4. - Спр. 548 (Вырезка из польской газеты «Дженник Киевски»). - 375 арк.

8. ЦДІАК України. - Ф. 274 (Киевское ГЖУ). - О. 5. - Спр. 17 (Циркуляр Департамента полиции.) 21 арк.

9. ЦДІАК України. - Ф. 361 (Канцелярия военного генерал-губернатора областей Австро-Венгрии, занятых по праву войны). - Оп. 1. - Спр. 132 (Сообщение военного генерал-губернатора Галиции). - 65 арк. 
10. ЦДІАК України. - Ф. 365 (Жандармское учреждение временного военного генерал-губернатора Галиции). - О. 1. - Спр. 32 (Сообщение генерал-квартирмейстера штаба Главнокомандующего армиями Юго-Западного фронта). -338 арк.

11. ЦЦДІАК України. - Ф. 442 (Канцелярия Киевского, Подольского и Волынского генерал-губернаторства). - Оп. 864. - Спр. 239 (Представление начальника Киевского ГЖУ). - 305 арк.

12. Центральний державний історичний архів України у м. Львові. - Ф. 858 (Головний народовий комітет). - Оп. 1. - Спр. 2 (Протоколи, донесення, огляди польської і зарубіжної преси та ін. документи про суспільно-політичне становище на польських землях у $1915-1916$ pp). -594 арк.

13. Dmowski R. Polityka polska i odbudowanie państwa / R. Dmowski. - Warszawa: In-t Wydawniczy Pax, 1989. - T. 2. $-1989 .-345 \mathrm{~s}$.

14. Garczyński T. Pomyłka / T. Garczyński // Kłosy Ukraińskie. - Kijów. - 1915. - Nr. 5. - S. 3.

15. Jaworski T. Konsolidacja polityczna Polski / T. Jaworski // Dziennik Kijowski. - Kijów. - 1916. - Nr. 244. - S. 1.

16. Kutrzeba S. Polska odrodzona 1914 - 1928 / Stanisław Kutrzeba. - Wyd. 4 niezm. - Warszawa: Gebethner i Wolff, 1935. - $321 \mathrm{~s}$.

17. Lewandowski J. Budowa państwa polskiego przed listopadem 1918 r. / J. Lewandowski // Niepodległosć Polski w 1918 r. a procesy panstwowotworcze w europie środkowo-wschodniej / red. Z. Mańkowskogo. - Lublin, 1996. $-203 \mathrm{~s}$.

18. Odezwy polskich stronnictw // Kłosy Ukraińskie. - Kijów. - 1914. - Nr. 9-12. - S. 25-26.

19. Opinja dnia // Dziennik Kijowski. - Kijów. - 1917. - Nr. 35. - S. 2.

20. Pajewski J. Odbudowa Panstwa Polskiego 1914 - 1918 / J. Pajewski. - Poznań: Wydawnictwo Poznańskie, 2005. $-353 \mathrm{~s}$.

21. Paszkowski E. Neutralność / E. Paszkowski // Dziennik Kijowski. - Kijów. - 1917. Nr. 290. - S. 1.

22. Sierpowski Stanisław. Mocarstwa wobec idei samostanowlenia i aspiracji nieoidległościowych w Europie Środkowej i Wschodniej w latach I Wojny swiatowej / S. Sierpowski // Niepodległosć Polski w 1918 r. a procesy panstwowotworcze w Europie środkowo-wschodniej / red. Z. Mańkowskogo. - Lublin, 1996. - 203 s.

23. Starczewski E. Chwila poważna // Dziennik Kijowski. - Kijów. - 1916. - Nr. 305. - S. 1.

24. Ursyn J. Na przelomie / J. Ursyn // Kłosy Ukraińskie. - Kijów. - 1916. - Nr. 15-18. - S. 25.

25. Znaczonca zgoda // Kłosy Ukraińskie. - Kijów. - 1916. - Nr. 2. - S. 9.

\section{REFERENCES:}

1. Boiechko V. Druha Richpospolyta 1914 - 1921 rr.: stanovlennia derzhavnosti / V. Boiechko. - Cherkasy: ChNU, 2016. $-408 \mathrm{~s}$.

2. Derzhavnyi arkhiv Lvivskoi oblasti. - F. 350 (Dyrektsiia politsii u Lvovi Halytskoho namisnytstva). Op. 1. - Spr. 3506 (Vidozva rosiiskoho imperatora Mykoly I do polskoho naselennia). - 4 ark.

3. Polskyi natsyonalnыi komytet // Nasha Volon. - Zhytomyr. - 1914. - № 302. - S. 3.

4. Polskyi seim // Zhyzn Volyni. - Zhytomyr. - 1916. - № 314. - S. 2.

5. Polskyi sъezd // Zhyzn Volyni. - Zhytomyr. - 1916. - № 39 - S. 3.

6. Protest poliakov // Zhyzn Volyni. - Zhytomyr. - 1916. № $301-$ S. 2.

7. Tsentralnyi derzhavnyi istorychnyi arikhiv Ukrainy u m. Kyievi (dali - TsDIAK Ukrainy). - F. 274 (Kyevskoe HZhU) - O. 4. - Spr. 548 (Vыrezka yz polskoi hazetb «Dzhennyk Kyevsky»). - 375 ark.

8. TsDIAK Ukrainy. - F. 274 (Kyevskoe HZhU). - O. 5. - Spr. 17 (Tsyrkuliar Departamenta polytsyy.) 21 ark.

9. TsDIAK Ukrainy. - F. 361 (Kantseliaryia voennoho heneral-hubernatora oblastei Avstro-Venhryy, zaniatыkh po pravu voinы). - Op. 1. - Spr. 132 (Soobshchenye voennoho heneral-hubernatora Halytsyy). - 65 ark.

10. TsDIAK Ukrainy. - F. 365 (Zhandarmskoe uchrezhdenye vremennoho voennoho heneral-hubernatora Halytsyy). - O. 1. - Spr. 32 (Soobshchenye heneral-kvartyrmeistera shtaba Hlavnokomanduiushcheho armyiamy Yuho-Zapadnoho fronta). -338 ark.

11. TsDIAK Ukrainy. - F. 442 (Kantseliaryia Kyevskoho, Podolskoho y Volonskoho heneral-hubernatorstva). - Op. 864. - Spr. 239 (Predstavlenye nachalnyka Kyevskoho HZhU). - 305 ark.

12. Tsentralnyi derzhavnyi istorychnyi arkhiv Ukrainy u m. Lvovi. - F. 858 (Holovnyi narodovyi komitet).Op. 1. - Spr. 2 (Protokoly, donesennia, ohliady polskoi i zarubizhnoi presy ta in. dokumenty pro suspilno-politychne stanovyshche na polskykh zemliakh u 1915 - 1916 rr). - 594 ark.

13. Dmowski R. Polityka polska i odbudowanie państwa / R. Dmowski. - Warszawa: In-t Wydawniczy Pax, 1989. - T. 2. $-1989 .-345 \mathrm{~s}$.

14. Garczyński T. Pomyłka / T. Garczyński // Kłosy Ukraińskie. - Kijów. - 1915. - Nr. 5. - S. 3. 
15. Jaworski T. Konsolidacja polityczna Polski / T. Jaworski // Dziennik Kijowski. - Kijów. - 1916. - Nr. 244. - S. 1.

16. Kutrzeba S. Polska odrodzona 1914 - 1928 / Stanisław Kutrzeba. - Wyd. 4 niezm. - Warszawa: Gebethner i Wolff, 1935. $-321 \mathrm{~s}$.

17. Lewandowski J. Budowa państwa polskiego przed listopadem 1918 r. / J. Lewandowski // Niepodległosć Polski w 1918 r. a procesy panstwowotworcze w europie środkowo-wschodniej / red. Z. Mańkowskogo. - Lublin, 1996. $-203 \mathrm{~s}$.

18. Odezwy polskich stronnictw // Kłosy Ukraińskie. - Kijów. - 1914. - Nr. 9-12. - S. 25-26.

19. Opinja dnia // Dziennik Kijowski. - Kijów. - 1917. - Nr. 35. - S. 2.

20. Pajewski J. Odbudowa Panstwa Polskiego 1914 - 1918 / J. Pajewski. - Poznań: Wydawnictwo Poznańskie, 2005. $-353 \mathrm{~s}$.

21. Paszkowski E. Neutralność / E. Paszkowski // Dziennik Kijowski. - Kijów. - 1917. Nr. 290. - S. 1.

22. Sierpowski Stanisław. Mocarstwa wobec idei samostanowlenia i aspiracji nieoidległościowych w Europie Środkowej i Wschodniej w latach I Wojny swiatowej / S. Sierpowski // Niepodległosć Polski w 1918 r. a procesy panstwowotworcze w Europie środkowo-wschodniej / red. Z. Mańkowskogo. - Lublin, 1996. - 203 s.

23. Starczewski E. Chwila poważna // Dziennik Kijowski. - Kijów. - 1916. - Nr. 305. - S. 1.

24. Ursyn J. Na przelomie / J. Ursyn // Kłosy Ukraińskie. - Kijów. - 1916. - Nr. 15-18. - S. 25.

25. Znaczonca zgoda // Kłosy Ukraińskie. - Kijów. - 1916. - Nr. 2. - S. 9

Стаття надійшла до редакиії 21.10.2017 p. 